\title{
Karakteristik, Tipologi, Urban Sprawl
}

\author{
Characteristics, Typology, Urban Sprawl
}

\author{
Firdaus, Febby Asteriani, Anissa Ramadhani \\ Fakultas Teknik Universitas Islam Riau
}

\begin{abstract}
Abstrak
Penelitian ini bertujuan untuk mengetahui karakteristik, tipologi, dan tingkat urban sprawl yang terjadi di Kota Pekanbaru. Sampel penelitian sejumlah 99 dari 7.646 jumlah bangunan yang terdigitasi. Mengetahui karakteristik dan tipe urban sprawl digunakan analisis deskriptif dengan pendekatan spasial dan untuk tingkat urban sprawl dilakukan dengan pemberian scoring pada variable urban sprawl. Hasil penelitian menunujukkan bahwa karakteristik urban sprawl dicirikan dengan penggunaan lahan terpisah yang terletak jauh dari pusat-pusat permukiman, kepadatan penduduk rendah sekitar $4.499 \mathrm{jiwa} / \mathrm{km}^{2}$, penggunaan mobil pribadi yang tinggi pada jam sibuk yakni sebesar 5.945 unit setiap hari. Tipe urban sprawl yang dominan adalah perembetan memanjang dan perembetan meloncat terjadi pada jalan arteri maupun kolektor, sedangkan perembetan meloncat terjadi di beberapa kelurahan. Kelurahan Delima dan Kelurahan Tuah Karya termasuk pada tipologi ke-1 dengan tingkat urban sprawl rendah, dan tipologi ke-2 dengan tingkat urban sprawl sedang terjadi di Kelurahan Sidomulyo Barat, sedangkan Kelurahan Simpang Baru termasuk pada tipologi ke-3 dengan tingkat urban sprawl tinggi.
\end{abstract}

Kata Kunci : karakteristik, tipologi, urban sprawl

\begin{abstract}
This study aims to determine the characteristics, typology, and levels of urban sprawl that occur in the city of Pekanbaru. The study sample numbered 99 out of 7,646 numbers of digitalized buildings. Knowing the characteristics and types of urban sprawl used descriptive analysis with a spatial approach and for the level of urban sprawl carried out by giving scoring to urban sprawl variables. The results of the study show that the characteristics of urban sprawl are characterized by separate land uses located far from residential centers, low population density of around 4,499 people / $\mathrm{km} 2$, high private car use during peak hours which is 5,945 units per day. The dominant type of urban sprawl is longitudinal infiltration and jumping leaks that occur on arterial roads and collectors, while leachates jump in several villages. The Delima and Tuah Karya Villages included in the 1st typology with a low level of urban sprawl, and the second typology with the level of urban sprawl was occurring in Sidomulyo Barat Village, while the Simpang Baru Village was included in the 3rd typology with high urban sprawl.
\end{abstract}

Keywords: characteristics, typology, urban sprawl

\section{PENDAHULUAN}

\section{Latar Belakang}

Pertumbuhan kota-kota di

Indonesia berlangsung sangat pesat, terutama di wilayah kota metropolitan diindikasikan dengan bertambahnya proporsi penduduk perkotaan yang dari tahun ke tahun terus meningkat. Dalam kurun tahun 1980-1990-an, terjadi peningkatan proporsi penduduk perkotaan dari $22 \%$ menjadi $31 \%$. Sensus penduduk 2000 menunjukkan bahwa jumlah penduduk perkotaan mecapai lebih dari 85 juta jiwa atau sekitar $42 \%$ dari total penduduk. Pada tahun 2020, jumlah penduduk perkotaan di perkirakan mencapai 132,5 juta jiwa atau sekitar 52\% dari total jumlah penduduk. (Sukamdi dkk, 1997).

Pertambahan jumlah penduduk perkotaan akan menyebabkan semakin tingginya permintaan kebutuhan guna lahan di pusat-pusat kota, permasalahan guna lahan dipusat kota adalah tidak seimbangnya ketersediaan lahan dengan kebtuhan guna lahan, nilai harga lahan yang relatif tinggi bila dibandingkan dengan nilai harga lahan di wilayah pinggiran kota. Untuk memenuhi kebutuhan lahan masyarakat, sebagian 
penduduk berupaya mencari lahan kearah wilayah pinggiran kota dalam rangka memenuhi kebutuhan kehidupan socialekonominya, kecendrungan penduduk yang mencari daerah baru untuk berusaha dan bermukim sehingga terjadi pemekaran kota dan tercipta pola pemanfaatan ruang yang baru yang terpisah-pisah, menyebar dan acak (sprawl).

Kota Pekanbaru terindikasi sedang menghadapi permasalahan urban sprawl, sebagai pusat kegiatan mengalami penyatuan fungsional dan munculnya densifikasi permukiman kota. Hal ini didukung oleh pembangunan gedung yang cenderung vertikal dipusat kota yang didasarkan pada isu keterbatasan lahan. Ekspansi wilayah pinggiran yang begitu cepat dan terus berlanjut tanpa kontrol perencanaan menimbulkan pola pembangunan yang terfragmentasi yang dapat mengakibatkan inefesiensi penggunaan lahan. Ketersediaan lahan yang terbatas sulit mengimbangi jumlah pertumbuhan penduduk, oleh sebab itu diperlukan pengawasan perencanaan pembangunan terutama di kawasan pinggiran.

Kecamatan Tampan berdasarkan data Pekanbaru dalam angka (2017) merupakan salah satu kawasan dengan tingkat kepadatan penduduk masih tergolong rendah dengan kepadatan penduduk sekitar 4.499 jiwa $/ \mathrm{km}^{2}$. Penggunaan lahan di Kecamatan Tampan tahun 2016 mencapai 4.506,41 Ha (Revisi RTRW Kota Pekanbaru, 2012) yang terdiri dari penggunaan lahan komersial seperti perdagangan dan jasa, permukiman, pendidikan, dan industri.

Orientasi penggunaan kendaraan pribadi berupa mobil mobil yang cukup tinggi juga menjadi ciri pendukung urban sprawl. Tercatat pada tahun 2016 penggunaan kendaraan pribadi di Kecamatan Tampan pada salah satu koridor utama yakni di Jl. HR. Soebrantas mencapai \pm 800 hingga \pm 1.189 unit mobil sedangkan untuk kendaraan roda dua mencapai \pm 2500 kendaraaan di setiap jamnya (Survey Traffic Counting, 2016).
Penggunaan kendaraan pribadi yang menjadi sarana transportasi utama masyarakat menjadi salah satu ciri penentu kawasan yang menjadi urban sprawl.

Berdasarkan pada latar belakang maka dirumuskan beberapa pertanyaan penelitian/research question terkait dengan urban sprawl, Bagaimana karakteristik, tipologi dan tingkat urban sprawl di Kecamatan Tampan?

\section{Tujuan}

Tujuan utama dari penelitian ini adalah untuk mengkaji kondisi urban sprawl di Kota Pekanbaru khususnya untuk mengetahui perkembangan kondisi fisik wilayah akibat adanya urban sprawl yang meliputi karakteristik, tipe, serta tingkat urban sprawl yang terjadi.

\section{KAJIAN LITERATUR}

Meningkatnya jumlah penduduk perkotaan berpengaruh kepada meningkatnya kebutuhan kehidupan masyarakat dari semua aspek; politik, ekonomi, sosial, budaya dan teknologi sehingga meningkatnya kegiatan penduduk perkotaan. Ketersediaan ruang di dalam kota tetap dan terbatas, maka meningkatnya kebutuhan ruang untuk tempat tinggal dan kedudukan fungsifungsi selalu akan mengambil ruang di daerah pinggiran kota. Gejala pengambil alihan lahan non urban di daerah pinggiran kota disebut sebagai "invasion". Proses perembetan kenampakan fisik kekotaan ke arah luar disebut "urban sprawl" (Yunus, 2000).

Urban sprawl atau dikenal dengan pemekaran kota merupakan bertambah luasnya kota secara fisik. Perluasan kota disebabkan semakin berkembangnya penduduk dan semakin tingginya arus urbanisasi. Semakin bertambahnya penduduk kota menyebabkan semakin bertambahnya kebutuhan masyarakat terhadap perumahan, perkantoran, dan fasilitas sosial ekonomi lain. Urban sprawl terjadi dengan ditandai adanya alih fungsi lahan yang ada di sekitar kota (urban periphery) mengingat terbatasnya lahan 
yang ada di pusat kota. (Rosul dalam Apriani, 2015)

Urban sprawl bisa dideskripsikan sebagai pembangunan yang tidak terencana, menyebar, kepadatan rendah, dan tidak terstruktur di kawasan pinggiran. Salah satu bentuk nyata dari proses urban sprawl di kawasan pinggiran adalah meningkatnya jumlah pembangunan perumahan yang tersebar di pinggiran kota. Dengan adanya pembangunan perumahan, otomatis membuat jaringan jalan menjadi bertambah dan muncul aktivitas ekonomi seperti komersial. (Setioko dalam Hanief, 2014)

Urban sprawl merupakan salah satu bentuk dari urban growth yang cenderung kearah negatif. Urban sprawl dapat juga didefinisikan sebagai salah satu bentuk perkembangan kota dari segi fisik dapat dilihat dari bertambahnya gedung secara vertikal maupun horisontal, yang diikuti dengan alih fungsi lahan di sekitar kota (urban periphery). Perumahan baru, jalan, dan bangunan komersial menyebabkan daerah perkotaan tumbuh lebih jauh ke pedesaan, dan meningkatkan kepadatan pemukiman di daerah yang sebelumnya bersifat pedesaan. Ukuran kota yang mengalami sprawl terus membesar seolah-olah menyatu dengan kota-kota di sekitarnya sehingga menjadikan dua atau lebih kawasan yang secara administratif berbeda (terpisah) namun jadi satu kesatuan kenampakan kekotaan (kota metropolitan) dengan bentuk dan fungsifungsi bangunan yang berkarakteristik kota.

Dari teori-teori diatas, bahwa Urban sprawl adalah perembetan kenampakan fisik kota yang terjadi secara menyebar, tidak terencana, tidak teratur, acak (leapfrog) yang terjadi di wilayah pinggiran atau di wilayah sekitar kota (urban periphery). Biasanya urban sprawl ini ditandai dengan meningkatnya jumlah pembangunan perumahan di kawasan pinggiran, perkembangan permukiman berkepadatan rendah, bertambahnya gedung secara vertikal maupun horizontal, penggunaan lahan terpisah dan penggunaan mobil yang tinggi. Urban sprawl ini merupakan salah satu fenomena penyebab berkembangan penggunaan lahan di kawasan pinggiran.

\section{Karakteristik Urban Sprawl}

Keberadaan sprawl ditandai dengan adanya beberapa perubahan pola guna lahan yang terjadi secara serempak, (Yunus, 2000):diantaranya: Pertama, Single-Use Zonin, Keadaan yang menunjukkan situasi kawasan komersial, perumahan dan area industri saling terpisah antara satu dengan yang lain. Kedua, LowDensity Zoning, Sprawl mencirikan adanya pertumbuhan yang terjadi di wilayah yang memiliki tingkat kepadatan penduduk rendah. Ketiga, Car-Dependent Communities, Area yang mengalami urban sprawl biasa dikenali dengan tingkat penggunaan mobil yang tinggi sebagai alat transportasi, kondisi ini biasa disebut dengan automobile dependeny. Kebanyakan aktivitas seperti berbelanja (commuting to work), membutuhkan mobil sebagai akibat dari isolasi area dari zona perumahan dengan kawasan industri dan kawasan komersial.

\section{Tipe Urban Sprawl}

Menurut Yunus (2000), secara garis besar ada tiga macam proses perluasan kekotaan (urban sprawl), yaitu : a) Tipe 1: Perembetan onsentris (Concentric Development/Low Density Continous Development) Tipe pertama ini oleh Harvey Clark (1971) disebut sebagai "low density, continous development" dan oleh Wallace (1980) disebut "concentric development". Jadi ini merupakan jenis perembetan areal kekotaan yang paling lambat. Tipe 2 :Perembetan Memanjang (Ribbon Development/Linear Development/Axial Development).

$$
\text { Tipe yang menunjukkan }
$$
ketidakmerataan perembetan areal kekotaan disemua bagian sisi-sisi luar dari pada daerah kota utama. Perembetan paling cepat terlihat di sepanjang jalur transportasi yang ada, khususnya yang bersifat menjari (radial) dari pusat kota. 
Daerah ini sepanjang rute transportasi utama merupakan tekanan paling berat dari perkembangan. Tipe 3: Perembetan yang Meloncat (Leap Frog Development/Checkerboard Development) Tipe perkembangan ini oleh kebanyakan pakar lingkungan dianggap paling merugikan, tidak efisien dalam arti ekonomi, tidak mempunyai nilai estetika dan tidak menarik. Perkembangan lahan kekotaannya terjadi berpencaran secara sporadis dan tumbuh di tengah-tengah lahan pertanian. Keadaan ini sangat menyulitkan pemerintah kota untuk membangun prasarana-prasarana fasilitas kebutuhan hidup sehari-hari. Pembiayaan untuk pembangunan jaringan-jaringannya sangat tidak sebanding dengan jumlah penduduk yang diberi fasilitas. Khususnya apabila dibandingkan dengan penduduk yang tinggal diareal kekotaan yang kompak.

\section{Faktor-faktor Penyebab Urban Sprawl}

Menurut Lee (dalam Yunus, 2005), terdapat 6 (enam) faktor yang berpengaruh kuat tehadap perkembangan ruang secara sentrifugal kearah luar (urban sprawling) dan mencerminkan variasi intensitas perkembangan ruang di daerah pinggiran kota.

a. Faktor Aksesibilitas

b. Faktor Pelayananan Umum

c. Faktor Karakteristik Pemilik Lahan

d. Faktor Keberadaan Peraturan yang Mengatur Tata Ruang.

e. Faktor Prakarsa Pengembang dan Nilai Lahan.

\section{Pengukuran Tingkat Urban Sprawl}

Terkait dengan pengukuran

sprawl, banyak peneliti yang telah menjelaskan cara pengukuran sprawl. Dari banyak variabel yang digunakan oleh berbagai peneliti dalam meneliti ukuran sprawl, kepadatan merupakan variabel utama dalam pengukuran sprawl. Tsai (dalam Apriani, 2015) telah mengklasifikasikan metrik keruangan yang digunakan dalam studi urban sprawl ke dalam 3 kelas, yaitu kepadatan, perbedaan guna lahan dan pola struktur keruangan, namun ketiga variabel tersebut masih sangat umum untuk menentukan ukuran sprawl. Menurut Galster et al, 2001 (dalam Apriani, 2015), Urban sprawl adalah pola pembangunan lahan yang menunjukkan level atau tingkatan terendah dari 8 dimensi, yaitu kepadatan penduduk, pembangunan dalam jangkauan jaringan jalan, konsentrasi kepadatan bangunan, pengelompokkan bangunan, pemusatan, penggunaan lahan campuran, jarak ke pusat kota dan kedekatan penggunaan lahan yang berbeda. Variabel tersebut dihitung dengan berdasarkan pada penggunaan lahan, namun ada beberapa variabel yang dianggap dapat diwakili oleh variabel lainnya seperti pemusatan dan jarak ke pusat kota. Penggunaan lahan campuran dan kedekatan lahan yang berbeda. Ewing, R et al (2002), mengukur urban sprawl dengan menggunakan variabel kepadatan bangunan, aksesibilitas jaringan jalan, penguatan pusat kota, dan Kedekatan penggunaan campuran, rumah, tempat kerja, dan fasilitas. Keempat indikator tersebut diukur, kemudian masing-masing ukuran dari variable tersebut di rata-rata kan dan dicari standar deviasinya untuk menentukan ukuran sprawl. Hasse John and Richard (dalam Apriani, 2015), mencoba mengukur sprawl pada unit perumahan dengan menggunakan 5 variabel sebagai karakteristik sprawl. Penelitian dilakukan dengan melihat perubahan atau penambahan perumahan baru dari tahun yang berbeda, kemudian diukur dengan menggunakan rumus dari masing-masing variabel, yaitu kepadatan bangunan, pola pembangunan lompatan katak (leapfrog), penggunaan lahan yang terpisah (segregeted land use), pembangunan dalam jangkauan jaringan jalan (highway strip), dan jarak ke pusat kota (Node Inaccessibillity).

\section{METODELOGI}

Penelitian ini dilakukan di Kota

Pekanbaru sebagai sampel diambil kawasan kecamatan Tampan dengan pertimbangan bahwa kecamatan tersebut 
sebagai kawasan yang terletak dikawasan paling pinggir di wilayah kota Pekanbaru, dilihat dari faktor eksternal dan internal teridentifikasi mengalami urban sprawl.

Teknik pengambilan sampel dalam penelitian ini menggunakan teknik simple random sampling dimana pengambilan sampel dari semua anggota populasi dilakukan secara acak tanpa memperhatikan strata yang ada didalam populasi. Populasi yang akan digunakan dalam penelitian ini adalah jumlah bangunan yang terdigitasi sejumlah 7.646 unit. Untuk menentukan jumlah titik uji akurasinya Lahan terbangun di Kecamatan Tampan pada masing-masing kelurahan dari perhitungan didapat kelurahan Simpang Baru 33 titik, kelurahan Sidomulyobarat 22 titik, kelurahan Tuahkarya 30 titik dan kelurahan Delima 15 titik.

Teknik analisis yang digunakan adalah analisis deskriptif, analisis spasial, dan analisis scoring. Analisis deskriptif digunakan untuk mendeskripsikan hasil dari kompilasi data dan menjelaskan hasil analisis spasial dengan bantuan GIS.

Metode pengumpulan data yang digunakan dalam penelitian ini dari Observasi dengan mengidentifikasi data melalui pengukuran serta pengambilan data secara langsung kelapangan. Kegiatan observasi ini dilakukan secara sistematis untuk menjajaki masalah dalam penelitian yang dilakukan. Observasi tidak terbatas pada orang tapi juga pada obyek-obyek berdasarkan fakta lapangan maupun data yang bersumber dari instansi-instansi terkait seperti BPS, dan Badan Pertanahan. Penelitian ini juga melakukan telaah pustaka dan studi dokumentasi yang ada hubungannya dengan obyek studi dengan cara mengambil gambar, lefleat/brosur objek, dan dokumentasi foto.

\section{Pengolahan dan Analisis Data}

Analisis Karakteristik Sprawl yang telah diidentifikasi dengan analisis deskriptif digunakan untuk menjelaskan seperti apa kondisi urban sprawl di Kecamatan Tampan yang ditinjau dari karakteristik urban sprawl yang dikemukakan dalam teori Struktur Tata Ruang Kota oleh Yunus tahun 2000 terdpat 3 (tiga) poin karakteristik yakni a) Penggunaan Lahan Terpisah (Single UseZoning), b) Kepadatan Rendah (Low Density-Zoning), c) Penggunaan Mobil Tinggi (Car Dependent Community)

Menganalisis Tipe Urban Sprawl di Kecamatan Tampan menggunakan metode Analisis Deskriptif dengan pendekatan analisis spasial. Analisis digunakan dalam pengolahan data SIG. Hasil analisis data spasial sangat bergantung pada lokasi objek yang bersangkutan (yang sedang dianalisis). Selanjutnya akan dilakukan uji akurasi interpretasi terhadap peta citra. Hal ini perlu dilakukan karena berkaitan dengan tingkat akurasi minimal dan validitas data hasil interpretasi citra satelit pada tahun 2016. Bila hasil interpretasi tidak memiliki batas minimal akurasi yang ditetapkan dan diterima secara logika, maka hasil interpretasi tidak dapat digunakan untuk pertimbangan pengambilan keputusan dan tindakan. Derajat hasil analisis dan evaluasi sangan tergantung pada hasil uji akurasi data hasil interpretasi.

Uji akurasi data hasil interpretasi citra tahun perekaman 2016 akan dibandingkan dengan hasil interpretasi kondisi lapangan melalui metode observasi langsung. Kesesuaian ini diukur dengan presentasi interpretasi masuk dan hasil interpretasi keluar (komisi dan omisi). Jenis uji akurasi yang akan digunakan dalam sasaran ini yakni Confusion Matrix Correlation.

Tabel 1. Matriks Kesalahan (Confusion Matrix)

\begin{tabular}{|c|c|c|c|c|c|c|c|}
\hline No & $\begin{array}{c}\text { Data } \\
\text { Acuan }\end{array}$ & A & B & C & $\begin{array}{c}\text { Komisi } \\
\text { Titik }\end{array}$ & $\begin{array}{c}\text { Omisi } \\
\text { Titik }\end{array}$ & $\begin{array}{c}\text { MA } \\
\text { \% }\end{array}$ \\
\hline 1 & A & & & & & & \\
\hline 2 & B & & & & & & \\
\hline 3 & C & & & & & & \\
\hline \multicolumn{2}{|c|}{ Total KH } & & & & & & \\
\hline
\end{tabular}

Sumber : Rony, 2010 
Keterangan : A, B, C (Objek yang diteliti)

$$
\begin{gathered}
\text { MA }=\frac{\text { Xcr Titik }}{\text { Xcr Titik }+ \text { Xo Titik }+ \text { Xco }} \times 100 \% \\
\text { KH }=\frac{\text { Jumlah Titik Murni Semua Kelas }}{\text { Jumlah Semua Titik }} \times 100 \%
\end{gathered}
$$

Sumber : Short dalam Loppies, 2010

Keterangan :

$\mathrm{KH}=$ Ketelitian seluruh hasil klasifikasi

MA = Ketelitian Pemetaan (mapping accuracy)

$\mathrm{Xcr}=$ Jumlahn Kelas $\mathrm{X}$ yang terkoreksi

$\mathrm{Xo}=$ Jumlah Kelas $\mathrm{X}$ yang masuk pada kelas lain (omisi)

$\mathrm{Xco}=$ Jumlah Kelas $\mathrm{X}$ tambahan darikelas lain (komisi)

\section{Menganalisis Tingkat Urban Sprawl di Kecamatan Tampan \\ Dilakukan menggunakan Analisis}

Scoring, untuk menentukan tipologi dan tingkat suatu objek. bertujuan untuk menentukan klasifikasi tingkat urban sprawl yang terjadi yang terdiri dari tipologi 1 dengan tingkat urban sprawl rendah, tipologi 2 dengan tingkat urban sprawl sedang dan tipologi 3 dengan tingkat urban sprawl tinggi.

Analisis scoring ini menggunakan variabel yang menjadi tolak ukur perhitungan dalam menentukan tingkat urban sprawl: 1) Analisis Variabel Sprawl, 2) Analisis Kepadatan Penduduk.Variabelnya adalah sebagai berikut:

Analisis Kepadatan Penduduk, Obyek dari analisis kepadatan penduduk adalah kelurahan yang teridentifikasi sprawl. Semakin tinggi kepadatan penduduk mengindikasikan tingkat sprawl yang semakin kecil.

Kepadatan Penduduk $=\frac{\text { Jumlah Penduduk }}{\text { Luas Lahan Terbangun }}$
Analisis Kepadatan Bangunan, Obyek dari analisis kepadatan bangunan adalah kelurahan yang teridentifikasi sprawl. Semakin tinggi kepadatan bangunan mengindikasikan tingkat sprawl yang semakin kecil.

$$
\text { Kepadatan Bangunan }=\frac{\text { Jumlah Unit Bangunan }}{\text { Luas Lahan Terbangun }}
$$

Analisis Jarak Ke Pusat Kota, dilakukan dengan menggunakan network analysis pada GIS.

Analisis Pembangunan dalam Jangkauan Jaringan Jalan dianlisis menggunakan indeks jaringan jalan melalui buffer jaringan jalan wilayah urban sprawl dengan teknik analisis spasial deskriptif dan deskriptif kuantitatif. Menurut Hasse, John and Richard (dalam Apriani, 2015) pada studi kasus di New Jersey, Buffer jaringan jalan utama pada wilayah urban sprawl adalah 300 feet atau setara dengan $100 \mathrm{~m}$. Kemudian pembangunan baru yang masuk kedalam buffer diberi nilai 1, kemudian pembangunan baru yang berada di luar buffer jaringan jalan di beri nilai 0 . Kemudian untuk menentukan tingkat sprawl, maka dapat dihitung dengan menggunakan index highway strip. Semakin besar rasio highways strip maka mengindikasikan tingkat sprawl semakin kecil seperti yang dirumuskan oleh Hasse John and Richard dalam Apriani (2015).

Indeks Highway Strip $=\frac{\text { Jumlah Bangunan Baru dalam Buffer Jaringan Jalan }}{\text { Jumlah Bangunan Baru Terbangun }}$

Analisis Pola Pembangunan Lompatan Katak, dilakukan dengan menghitung jarak pusat bangunan maupun permukiman baru terhadap pusat permukiman lama dalam kelurahan yang terfragmentasi sprawl. Perhitungan jarak dilakukan dengan menggunakan network analysis. Hasilnya dimasukkan kedalam rumus index leap frog yang dirumuskan oleh Hasse John and 
Richard (dalam Apriani, 2015). Semakin tinggi index leap frog menunjukkan bahwa tingkat sprawl semakin besar.

Indeks Leap frog

Total jarak bangunan baru yang terfagmentasi terhadap bangunan lama Jumlah Bangunan Baru

Tahap selanjutnya adalah mengklasifikasikan masing-masing variabel karakteristik urban sprawl kedalam 3 tingkatan yang bertujuan untuk mempermudah melakukan scoring, karena masing-masing variabel mengindikasikan tingkat sprawl yang sama. Varibel tersebut sebagao berikut:

\section{1) Analisis Klasifikasi Karakteristik Urban Sprawl}

\# Klasifikasi Kepadatan Penduduk, Hasil perhitungan kepadatan penduduk akan diklasifikasikan menjadi 3 kelas. Kepadatan penduduk tinggi, sedang, dan rendah. Semakin rendah kepadatan penduduk maka mengindikasikan semakin besar tingkat sprawl.

* Klasifikasi Kepadatan Bangunan, Hasil perhitungan kepadatan bangunan akan diklasifikasikan menjadi 3 kelas. Kepadatan bangunan tinggi, sedang, dan rendah. Semakin rendah kepadatan bangunan maka mengindikasikan semakin besar tingkat sprawl.

Klasifikasi Jarak Ke Pusat Kota, Hasil analisis jarak perumahan ke pusat kota (CBD) akan diklasifikasikan menjadi 3 kelas. Semakin jauh jarak perumahan yang berada di kelurahan yang teridentifikasi sprawl, maka mengindikasikan semakin besar tingkat urban sprawl.

* Klasifikasi Pembangunan dalam jangkauan jaringan jalan, Indeks Pembangunan dalam jangkauan jaringan jalan pada kelurahan yang teridentifikasi sprawl akan diklasifikasikan kedalam 3 kelas. Semakin kecil rasio nya maka mengindikasikan tingkat sprawl semakin besar.
Klasifikasi Pembangunan Lompatan Katak, Hasil dari perhitungan index leap frog di semua kelurahan yang teridentifikasi sprawl akan di klasifikan menjadi 3, yaitu tinggi, sedang, dan rendah. Klasifikasi tinggi menunjukkan bahwa tingkat urban sprawl pada kelurahan tersebut semakin besar.

Range Kelas $=\frac{\text { Nilai } \text { Tertinggi }- \text { Nilai Terendah }}{\text { Jumlah Kelas }}$

\section{2) Analisis Tingkat Urban Sprawl}

Untuk menentukan tingkat urban sprawl dilakukan dengan pengukuran scoring. Tabel indikator pengukuran scoring bertujuan untuk menyamakan input variabel yang dijadikan sebagai acuan dalam pemberian skor dalam mengukur tingkat urban sprawl. Variabel-variabel sprawl yang telah di klasifikasikan akan diskoring sesuai dengan indikasi tingkat sprawl yang dapat dilihat seperti pada tabel 3.5 berikut ini.

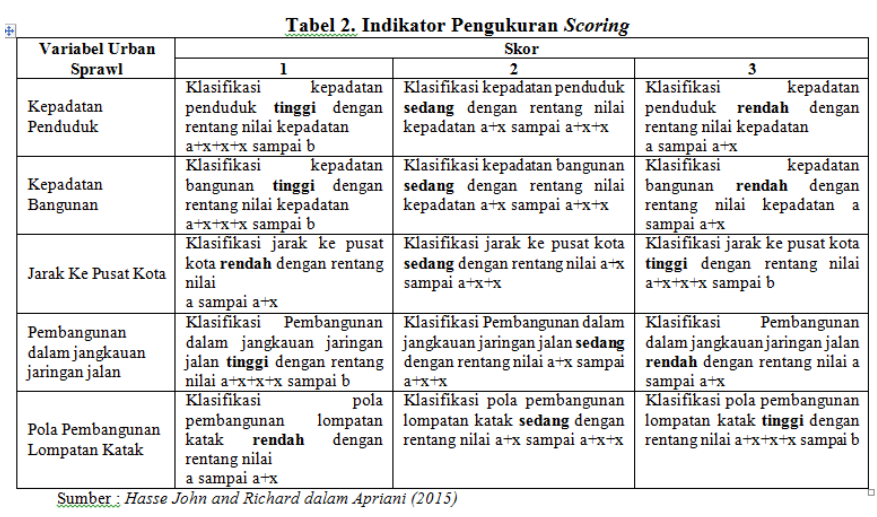

Keterangan :

a : Nilai terendah

$\mathbf{x}$ : Rentang nilai

b : Nilai tertinggi

Pengukuran skoring tersebut memiliki 3 kelas yakni sebagi berikut :

- Skor 1 : menunjukkan pengaruh variabel terhadap tingkat sprawl rendah

- Skor 2 : menunjukkan pengaruh variabel terhadap tingkat sprawl sedang

- Skor 3 : menunjukkan pengaruh variabel terhadap tingkat sprawl tinggi 
Tabel diatas digunakan sebagai dasar dalam memberikan skor pada kelurahan yang teridentifikasi sprawl dengan beracuan pada hasil analisis klasifikasi karakteristik sprawl yang telah dilakukan. Kemudian pengukuran urban sprawl pada kelurahan yang teridentifikasi sprawl dapat dilakukan dengan menjumlahkan semua skor .

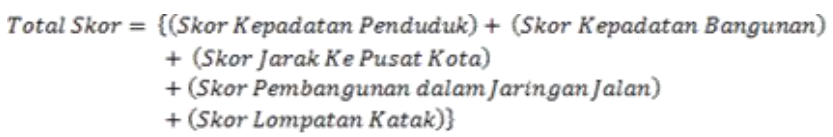

Setelah mendapatkan total skor untuk masing-masing kelurahan yang teridentifikasi sprawl, selanjutkan dilakukan pengklasifikasian untuk membentuk 3 tipologi. Pengklasifikasian dapat dilakukan dengan mencari range kelas.

Range Kelas $=\frac{\text { Nilai Tertinggi }- \text { Nilai Terendah }}{\text { Jumlah } \text { Kelas }}$

Dari hasil range kelas maka dapat dibentuk 3 tipologi, yakni :

- Tipologi 1 : Tingkat

Urban Sprawl Rendah

- Tipologi 2 : Tingkat Urban Sprawl Sedang

- Tipologi 3 : Sprawl Tinggi

\section{HASIL DAN ANALISIS}

\section{Analisis Karakteristik Urban Sprawl di Kecamatan Tampan}

\section{Penggunaan Lahan Terpisah} (Single Use Zoning)

Hasil analisis peta kawasan dapat dilihat bahwa penggunaan lahan pusat perbelanjaan komersial skala besar Mall SKA adalah lokasi lahan sangat jauh terpisah dari pusat-pusat permukiman. Penggunaan lahan yang terpisah ini mengharuskan masyarakat menggunakan sarana transportasi pribadi maupun transportasi umum untuk mengunjunginya, karena memiliki jarak yang relatif cukup jauh. Mengenai penggunaan lahan terpisah di Kecamatan Tampan dapat dilihat pada gambar yang diperoleh dari citra satelit google earth berikut dibawah ini.

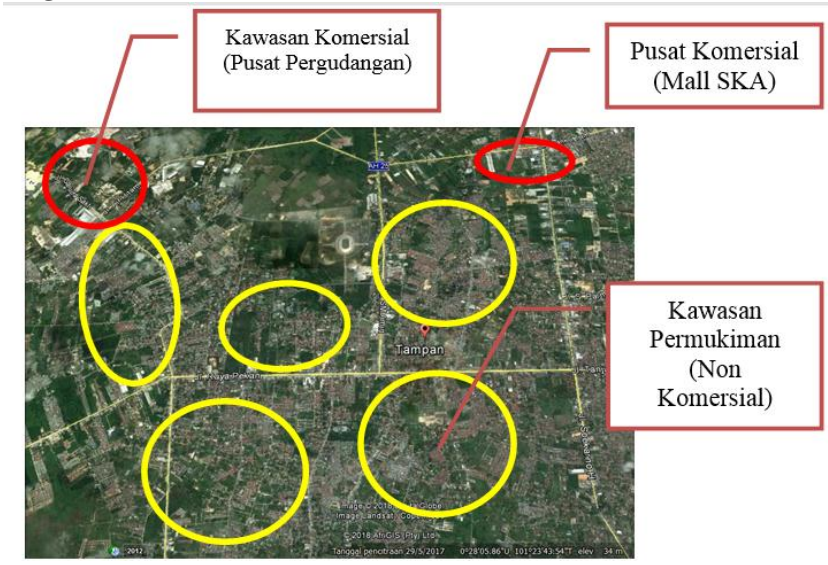

Gambar 1. Penggunaan Lahan Terpisah di Kecamatan Tampan

Sumber : Google Earth, 2018

\section{Kepadatan Rendah (Low Density Zoning) \\ Berdasarkan data Pekanbaru dalam} angka 2017, kepadatan penduduk Kecamatan Tampan berjumlah sekitar $4.499 \mathrm{jiwa} / \mathrm{km}^{2}$, sangat rendah sekitar 7\% jika dibandingkan dengan kepadatan penduduk kecamatan dikawasan pusat kota seperti kecamatan Sukajadi yang berjumlah sekitar $12.597 \mathrm{Km} 2$, kecamatan Pekanbarukota berjumlah $11.10 \mathrm{Km} 2$ dan Kecamatan Limapuluh. Teori yang dikemukakan Yunus (2000), bahwa salah satu yang mencirikan urban sprawl yakni suatu wilayah dengan tingkat kepadatan penduduk yang rendah. Dalam kondisi kepadatan penduduk rendah ini juga dilakukan pembangunan secara terusmenerus. Hasil analisis penggunaan lahan dengan metode GIS (Gheograpic Information System) menunjukkan penggunaan lahan terbangun tahun 2016 di Kecamatan Tampan adalah $37,80 \mathrm{~km}^{2}$ dengan tingkat kepadatan penduduk 4.499 jiwa $/ \mathrm{km}^{2}$. 
Tabel 4. Luas Lahan Terbangun di

Kecamatan Tampan Tahun 2016

\begin{tabular}{|c|c|c|c|c|}
\hline No & 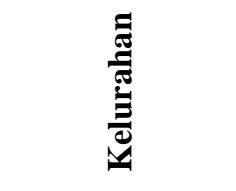 & 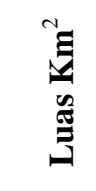 & 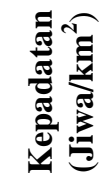 & 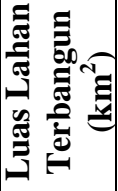 \\
\hline 1 & Simpang Baru & 23,59 & 2.579 & 17,98 \\
\hline 2 & Sidomulyobarat & 13,69 & 4.504 & 7,28 \\
\hline 3 & Tuahkarya & 12,09 & 8.190 & 7,11 \\
\hline 4 & Delima & 10,44 & 4.555 & 5,43 \\
\hline \multicolumn{2}{|c|}{ Jumlah } & 59.81 & 4.499 & $\mathbf{3 7 , 8 0}$ \\
\hline
\end{tabular}

Sumber : Hasil Analisis, 2018

\section{Penggunaan Mobil Tinggi (Car Dependent Comunity)}

Hasil

survey

lapangan

sebagaimana tabel 5. bahwa penggunaan mobil di Kecamatan Tampan pada salah satu ruas jalan utama yakni Jl. HR. Soebrantas tergolong tinggi yakni mencapai 1.827 unit mobil pada Koridor Pekanbaru-Kampar yang berlangsung selama pukul 06.00-08.00 WIB. Sedangkan penggunaan mobil tertinggi untuk Koridor Kampar-Pekanbaru adalah sebanyak 2.303 unit yang berlangsung selama pukul 16.00-18.00 WIB. Dalam waktu sehari yang dibagi pada jam-jam sibuk yakni 06.00-08.00, 11.00-13.00 dan 16.00-18.00 dapat dilihat jumlah kendaraan mobil pada Koridor tersebut mencapai 5.065 unit mobil dan untuk Koridor Kampar-Pekanbaru mencapai 5.945 unit mobil. Pemilihan waktu-wakru tersebut dinilai cocok untuk dilakukan perhitungan jumlah kendaraan karena merupakan waktu-waktu sibuk para pengguna jalan untuk melakukan aktifitasnya.

Menurut (Yunus 2000), bahwa area yang mengalami urban sprawl biasa dikenali dengan tingkat penggunaan mobil yang tinggi sebagai alat transportasi, kondisi ini biasa disebut dengan automobile dependeny. Kebanyakan aktivitas seperti berbelanja (commuting to work), bekerja, dan rekreasi, membutuhkan mobil sebagai akibat dari adanya isolasi atau gap area dari zona perumahan dengan kawasan komersial, lokasi pekerjaan hingga ruang terbuka hijau.
Tabel 5. Penggunaan Kendaraan Mobil di Kecamatan Tampan Tahun 2016 (Jl. HR. Soebrantas)

\begin{tabular}{|c|l|c|}
\hline \multirow{4}{*}{ No } & Koridor & $\begin{array}{c}\text { Sedan, Jeep, } \\
\text { Station } \\
\text { Wagon }\end{array}$ \\
\hline \multirow{4}{*}{1} & Jl. HR. Soebrantas (Pekanbaru-Kampar) \\
\cline { 2 - 3 } & Pukul 06.00-08.00 & 1.827 \\
\cline { 2 - 3 } & Pukul 11.00-13.00 & 1.622 \\
\cline { 2 - 3 } & Pukul 16.00-18.00 & 1.616 \\
\cline { 2 - 3 } & \multicolumn{1}{|c|}{ Jumlah } & $\mathbf{5 . 0 6 5}$ \\
\hline \multirow{4}{*}{2} & Jl. HR. Soebrantas (Kampar- Pekanbaru) \\
\cline { 2 - 3 } & Pukul 06.00-08.00 & 1.381 \\
\cline { 2 - 3 } & Pukul 11.00-13.00 & 2.261 \\
\cline { 2 - 3 } & Pukul 16.00-18.00 & 2.303 \\
\cline { 2 - 3 } & \multicolumn{2}{|c|}{ Jumlah } \\
\hline
\end{tabular}

Sumber : Inventaris TC, 2016

Tabel 6. Perbandingan Penggunaan

Kendaraan Mobil di Jl. HR. Soebrantas dan Jl. Arifin Ahmad Tahun 2016

\begin{tabular}{|c|c|c|c|}
\hline \multirow[b]{2}{*}{ No } & \multirow[b]{2}{*}{ Waktu } & \multicolumn{2}{|c|}{ Koridor } \\
\hline & & $\begin{array}{c}\text { Jl. HR. } \\
\text { Soebrantas } \\
\text { (Timur- } \\
\text { Barat) }\end{array}$ & $\begin{array}{c}\text { Jl. Arifin } \\
\text { Ahmad } \\
\text { (Timur- } \\
\text { Barat) }\end{array}$ \\
\hline \multirow{4}{*}{1} & Pukul 06.00-08.00 & 1.827 & 1.461 \\
\hline & Pukul 11.00-13.00 & 1.622 & 1.201 \\
\hline & Pukul 16.00-18.00 & 1.616 & 1.902 \\
\hline & Jumlah & 5.065 & 4.564 \\
\hline \multirow{5}{*}{2} & & $\begin{array}{c}\text { Jl. HR. } \\
\text { Soebrantas } \\
\text { (Barat- } \\
\text { Timur) } \\
\end{array}$ & $\begin{array}{c}\text { Jl. Arifin } \\
\text { Ahmad } \\
\text { (Barat- } \\
\text { Timur) }\end{array}$ \\
\hline & Pukul 06.00-08.00 & 1.381 & 1.084 \\
\hline & Pukul 11.00-13.00 & 2.261 & 1.095 \\
\hline & Pukul 16.00-18.00 & 2.303 & 1.777 \\
\hline & Jumlah & 5.945 & 3.956 \\
\hline
\end{tabular}

Sumber : Inventaris TC, 2016

Berdasarkan pada tabel 6. bahwa secara keseluruhan penggunaan mobil tertinggi terdapat pada Jalan. $\mathrm{H}$ R. Soebrantas dengan total penggunaan kendaraan 5.945 unit dalam satu hari (jam sibuk) pada rute timur-barat (KamparPekanbaru). Sedangkan untuk J1. Arifin Ahmad total penggunaan kendaraan tertinggi adalah 4.564 unit yakni pada koridor timur-barat (Jl. Soekarno Hatta-Jl. Sudirman) dalam waktu satu hari (jam sibuk). Kondisi ini memberikan gambaran bahwa Jl.. HR. Soebrantas jauh lebih tinggi apabila dibandingkan dengan jalan Jalan 
Arifin Ahmad yang memiliki karakteristik jalan yang relatif sama.

\section{Analisis Tipe Urban Sprawl di Kecamatan Tampan}

Adapun tipe urban sprawl yang terjadi di Kecamatan Tampan yakni tipe perembetan memanjang (ribbon development) dan perembetan yang meloncat (Leap Frog Development). Perembetan memanjang yakni tipe ini menunjukkan ketidakmerataan perembetan areal kekotaan disemua bagian sisi-sisi luar dari pada daerah kota utama. Perembetan paling cepat terlihat di sepanjang jalur transportasi yang ada, khususnya yang bersifat menjari (radial) dari pusat kota. Jaringan transportasi memegang peranan yang sangat penting dalam proses perembetan tipe ini. Berdasarkan peta persebaran lahan terbangun di Kecamatan Tampan dapat dilihat bahwa penggunaan lahan terbangun umumnya mengikuti jalur transportasi yang ada sebelumnya.

Pada jenis jalan arteri Jl. HR. Soebrantas, Jl. Soekarno Hatta, Jl. SM. Amin, dan Jl. Tuanku Tambusai, mayoritas digunakan untuk aktivitas komersial seperti perdagangan dan jasa, pendidikan, kesehatan, peribadatan dan lain sebagainya. Pada jalan kolektor J1. Delima, Jl. Kayu Jati, Jl. Cipta Karya, Jl. Suka Karya, Jl. Taman Karya ditemukan aktivitas-aktivitas yang berkaitan dengan aktivitas perdagangan dan jasa, pendidikan, peribadatan dan juga ditemukan aktivitas permukiman.

\section{Uji Akurasi Interpretasi}

Uji akurasi interpretasi dilakukan dengan metode Short. Uji akurasi merupakan tahap yang penting dalam proses pengekstrasian dari penginderaan jauh. Uji akurasi perlu dilakukan karena berkaitan dengan tingkat akurasi minimal dan validitas data hasil interpretasi Citra Satelit Ikonos pada tahun 2016, dimana data ini digunakan sebagai dasar analisis dan evaluasi dengan cara membandingkan hasil interpretasi penggunaan lahan terbangun dengan kondisi sebenarnya dilapangan, melalui metode observasi langsung ke lapangan. Jumlah sampel yang digunakan adalah 100 titik yang tersebar diseluruh Kecamatan Tampan. Hasil uji berdasarkan table 7 mennjukkan bahwa dari 100 titik sampel yang tersebar di Kecamatan Tampan, 94 titik yang sesuai dengan kondisi eksisting, 6 titik yang tidak sesuai antara kondisi eksisting dengan peta.

Tabel 7. Matriks Kesalahan (Coffusion Matrix)

\begin{tabular}{|c|c|c|c|c|c|c|}
\hline No & Peta & 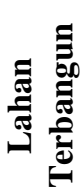 & 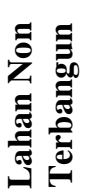 & 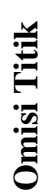 & 覀美 & $\underbrace{8}_{i}$ \\
\hline 1 & $\begin{array}{l}\text { Lahan } \\
\text { Terbangun }\end{array}$ & 94 & 0 & 0 & 0 & 94,00 \\
\hline 2 & $\begin{array}{l}\text { Lahan } \\
\text { Non } \\
\text { Terbangun }\end{array}$ & 6 & 0 & 0 & 6 & 6,00 \\
\hline \multicolumn{2}{|r|}{ Total } & 100 & 0 & 0 & 6 & \\
\hline
\end{tabular}

Sumber : Hasil analisis, 2018

$$
\begin{aligned}
& \text { MA }=\frac{\text { Xcr Titik }}{\text { Xcr Titik }+ \text { Xo Titik }+ \text { Xco }} \times 100 \% \\
& K H=\frac{\text { Jumlah Titik Murni Semua Kelas }}{\text { Jumlah Semua Titik }} \times 100 \%
\end{aligned}
$$

Keterangan :

$\mathrm{KH}=$ Ketelitian seluruh hasil klasifikasi

MA $=$ Ketelitian Pemetaan

(mapping accuracy)

$\mathrm{Xcr} \quad=$ Jumlahn Kelas $\mathrm{X}$ yang terkoreksi

Xo = Jumlah Kelas $\mathrm{X}$ yang masuk pada kelas lain (omisi)

Xco = Jumlah Kelas $\mathrm{X}$ tambahan dari kelas lain (komisi)

- Lahan Terbangun

$$
\begin{aligned}
& \text { MA }=\frac{\text { Xcr Titik }}{\text { Xcr Titik+Xo Titik+Xco } \times 100 \%} \\
& M A=\frac{94}{94+0+6} \times 100 \% \\
& M A=\frac{94}{100} \times 100 \% \\
& M A=94 \%
\end{aligned}
$$


- Lahan Non Terbangun

$$
\begin{aligned}
M A & =\frac{\text { Xcr Titik }}{\text { Xcr Titik }+ \text { Xo Titik }+ \text { Xco }} \times 100 \% \\
M A & =\frac{0}{0+6+0} \times 100 \% \\
M A & =\frac{0}{6} \times 100 \% \\
M A & =0 \%
\end{aligned}
$$

- Ketelitian seluruh hasil klasifikasi

$$
\begin{aligned}
& \text { KH }=\frac{\text { Jumlah Titik Murni Semua Kelas }}{\text { Jumlah Semua Titik }} \times 100 \% \\
& K H=\frac{94}{100} \times 100 \% \\
& K H=94 \%
\end{aligned}
$$

Tingkat ketelitian uji akurasi yang dilakukan terhadap peta Citra Satelit Ikonos tahun 2016 dengan kondisi eksisting adalah 94\%. Nilai ambang batas pada uji akurasi interpretasi metode Short adalah sebesar 85\%, nilai tersebut merupakan batas minimum untuk dapat diterimanya suatu pemetaan penggunaan lahan berbasis citra penginderaan jauh. Nilai uji akurasi yang dilakukan memperoleh tingkat ketelitian sebesar 94\% dengan kesalahan komisi sebesar 6,38\%. Hasil ini menunjukkan bahwa interpretasi Citra Ikonos dapat diterima karena telah memenuhi persyaratan batas minimal ketelitian interpretasi data penginderaan jauh.

Tingkat kesesuaian antara peta lahan terbangun dengan kondisi eksisting pada tabel 8 dijelaskan bahwa 33 titik uji akurasi di Kelurahan Simpangbaru terdapat 2 titik yang tidak sesuai peta dengan kondisi eksisting, dua titik tersebut merupakan lahan terbangun yang dimanfaatkan untuk kegiatan perdagangan dan jasa, bangunan ruko tersebut dibangun tahun 2017 dan belum beraktifitas.

Pada kelurahan Sidomulyobarat 22 titik dilakukan uji akurasi terdapat 2 titik yang tidak teridentifikasi pada peta citra, lahan tidak terbangun tersebut adalah kawasan perumahan yang sedang dilakukan proses pembangunan sejak tahun 2017 dan kawasan lahan perdagangan dan jasa berupa ruko 2 lantai yang dimanfaatkan untuk swalayan ini dibangun pada tahun 2017.

Sementara dari Kelurahan Tuahkarya 30 titik yang dilakukan uji terdapat 2 titik yang tidak sesuai antara peta dengan kondisi eksisting. Titik tersebut ditemukan berupa lahan terbangun, namun pada peta teridentifkasi sebagai lahan non terbangun. Lahan

\begin{tabular}{|c|c|c|c|c|c|}
\hline \multirow[b]{3}{*}{ No } & \multirow[b]{3}{*}{ Kelurahan } & \multicolumn{4}{|c|}{016} \\
\hline & & \multirow{2}{*}{ 苞 } & \multirow{2}{*}{ 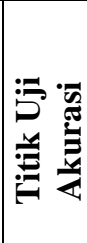 } & \multicolumn{2}{|c|}{$\begin{array}{c}\text { Tingkat } \\
\text { Kesesuaian }\end{array}$} \\
\hline & & & & 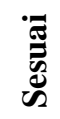 & 㐘 \\
\hline 1 & Simpangbaru & 2.542 & 33 & 31 & 2 \\
\hline 2 & Sidomulyobarat & 1.685 & 22 & 20 & 2 \\
\hline 3 & Tuahkarya & 2.295 & 30 & 28 & 2 \\
\hline 4 & Delima & 1.124 & 15 & 15 & 0 \\
\hline & Jumlah & 7.646 & 100 & 94 & 6 \\
\hline
\end{tabular}
terbangun tersebut berupa toko material bangunan dengan cakupan kecil dan mesjid yang sedang dalam tahap pembangunan (renovasi) yang dibangun pada tahun 2018.

Tabel 8. Titik dan Hasil Uji Akurasi Lahan Terbangun di Kecamatan Tampan Tahun

Sumber : Hasil Analisis, 2018

Perbedaan keakurasiaan yang terjadi antara peta citra dan kondisi eksisting yang dilakukan di Kecamatan Tampan ini tentunya disebabkan karena adanya rentang waktu antara peta citra yakni citra 2016 yang dibandingkan dengan kondisi eksisting yang dilakukan pada tahun 2018. Kondisi ini tentu menjadi salah satu penyebab perbedaan yang muncul pada uji akurasi ini karena tentunya pertumbuhan penduduk dan pertumbuhan pemanfaatan lahan yang terus berkembang dari waktu ke waktu namun dapat diasumsikan bahwa perkembangan lahan terbangun yang terjadi dalam kurun waktu 2 tahun tersebut tidak signifikan sehingga peta ini dapat diterima. 


\section{Analisis Tingkat Urban Sprawl di Kecamatan Tampan}

Analisis tingkat urban sprawl ini akan dilakukan dengan menggunakan 5 (lima) variabel utama yakni terdiri analisis kepadatan penduduk, analisis kepadatan bangunan, analisis jarak ke pusat kota, analisis pembangunan dalam jangkauan jaringan jalan, dan analisis pola pembangunan lompatan katak. Hasil dari analisis diklasifikasikan kedalam 3 tingkatan yang akan berpengaruh terhadap ukuran sprawl. Klasifikasi dilakukan dalam ukuran yang relatif (tergantung dari hasil analisis yang dilakukan pada masingmasing variabel).

\section{Analisis Kepadatan Penduduk}

Analisis kepadatan penduduk dilakukan dengan menggunakan data jumlah penduduk yang dibagi dengan luas lahan terbangun pada masing-masing kelurahan di Kecamatan Tampan. Untuk lebih jelasnya dapat dilihat pada tabel berikut ini.

Tabel 9. Analisis Kepadatan Penduduk di Kecamatan Tampan Tahun 2016

\begin{tabular}{|c|c|c|c|c|}
\hline No & Kelurahan & 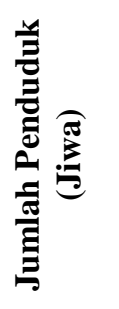 & 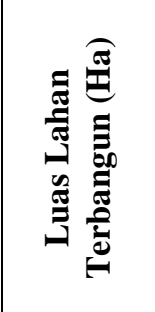 & 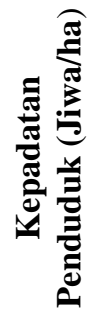 \\
\hline 1 & Simpangbaru & 60.844 & $1.797,90$ & 34 \\
\hline 2 & Sidomulyobarat & 61.656 & 728,34 & 85 \\
\hline 3 & Tuahkarya & 99.013 & 711,29 & 139 \\
\hline 4 & Delima & 47.549 & 543,15 & 88 \\
\hline & Jumlah & $\begin{array}{c}269.06 \\
2\end{array}$ & 80,68 & 86 \\
\hline
\end{tabular}

Sumber: BPS Pekanbaru, Arcgis 10.1 dan Hasil analisis, 2018

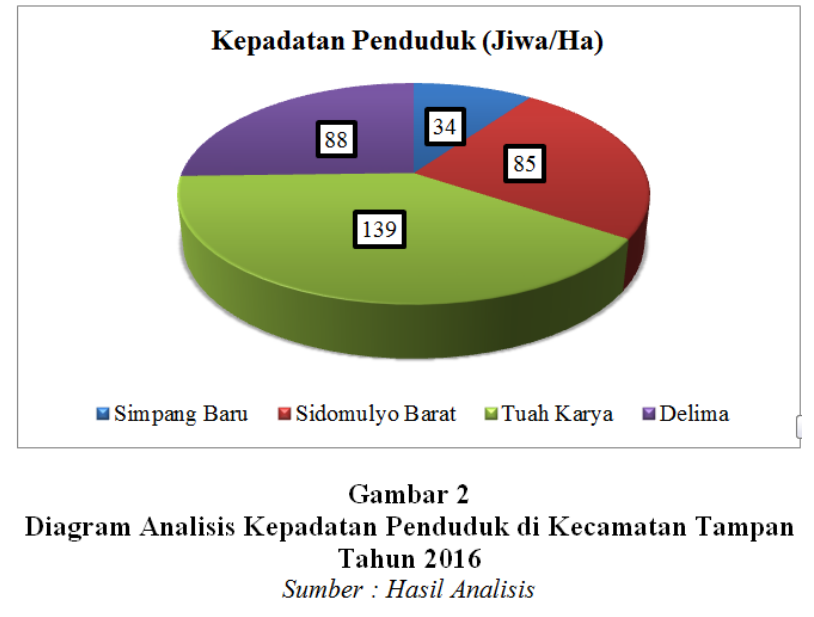

Berdasarkan perhitungan kepadatan penduduk pada tabel 9 dan diagram 5.7 bahwa kepadatan penduduk kawasan tertinggi adalah Kelurahan Tuahkarya dengan tingkat kepadatan penduduk $139 \mathrm{jiwa} / \mathrm{ha}$, sedangkan terendah adalah di Kelurahan Simpangbaru dengan 34 jiwa/ha. Berdasarkan pada kepadatan penduduk tertinggi dan terendah kemudian dicari rentang nilai, sehingga didapat klasifikasikan kepadatan penduduk rendah, kepadatan penduduk sedang, dan kepadatan penduduk tinggi. Kelurahan dengan kepadatan penduduk rendah mengindikasikan tingkat urban sprawl yang semakin tinggi, sedangkan kelurahan dengan kepadatan penduduk tinggi mengindikasikan tingkat urban sprawl yang semakin rendah. Untuk menentukan range dan klasifikasi pada kepadatan penduduk dapat dilihat berikut ini.

Range Kelas $=\frac{\text { Nilai } \text { Tertinggi }- \text { Nilai Terendah }}{\text { Jumlah Kelas }}$

$=\frac{139 \mathrm{jiwa} / \mathrm{ha}-34 \mathrm{jiwa} / \mathrm{ha}}{3}$

$=35 \mathrm{jiwa} / \mathrm{ha}$ 
Tabel 10. Klasifikasi Kepadatan Penduduk di Kecamatan Tampan

\begin{tabular}{|c|c|c|c|c|}
\hline No & $\begin{array}{c}\text { Range } \\
\text { Kelas }\end{array}$ & Kelurahan & Klasifikasi & Skor \\
\hline 1 & $34-69$ & $\begin{array}{c}\text { Simpang } \\
\text { Baru }\end{array}$ & Rendah & 3 \\
\hline 2 & $69-104$ & $\begin{array}{c}\text { Sidomulyo } \\
\text { Barat dan } \\
\text { Delima }\end{array}$ & Sedang & 2 \\
\hline 3 & $\begin{array}{c}104- \\
139\end{array}$ & Tuah Karya & Tinggi & 1 \\
\hline
\end{tabular}

Sumber : Hasil analisis, 2018

Klasifikasi rendah di Kelurahan Simpangbaru dengan range 34-69 jiwa/ha ditunjukkan pada table 10. Hal ini dipengaruhi oleh luas wilayah dan luas bangunan kelurahan terbesar di Kecamatan Tampan dengan luas wilayah $23,59 \mathrm{~km}^{2}$ dan luas lahan terbangun 1.797,90 ha atau $17,98 \mathrm{~km}^{2}$. Namun dengan kondisi luas wilayah yang besar tidak diimbangi dengan jumlah penduduk yang ada yakni 60.844 jiwa sehingga mengakibatkan kelurahan ini tergolong dalam tingkat kepadatan penduduk rendah. Kelurahan Simpang Baru merupakan salah satu kelurahan yang berbatasan langsung dengan Kabupaten Kampar sehingga masih adanya ditemukan aktifitas pertanian maupun perkebunan.

Klasifikasi kepadatan penduduk sedang dengan range 69-104 jiwa/ha yakni Kelurahan Sidomulyo Barat dan Kelurahan Delima. Kedua kelurahan ini tergolong kedalam kelas sedang karena jumlah penduduk dan penggunaan lahan terbangun yang tergolong seimbang. Dengan luas lahan terbangun 728,34 ha tercatat jumlah penduduk 61.656 jiwa di Kelurahan Sidomulyo Barat, sedangkan Kelurahan Delima dengan luas lahan terbangun 543,15 ha terdapat 47.549 jiwa. Kedua kelurahan ini mendominasi aktifitas komersial dan permukiman yang mencirikan bagian dari aktifitas perkotaan.

Sedangkan untuk klasifikasi tinggi dengan nilai range 104-139 jiwa/ha terdapat di Kelurahan Tuah Karya. Kelurahan Tuah Karya merupakan kelurahan dengan jumlah penduduk tertinggi di Kecamatan Tampan dengan
99.013 jiwa dengan luas lahan terbangun $711,29 \mathrm{~km}^{2}$ membuat kelurahan ini memiliki tingkat kepadatan penduduk yang tinggi. Kelurahan ini sama halnya dengan Kelurahan Sidomulyo Barat dan Kelurahan Delima yang didominasi terhadap aktifitas komersial dan permukiman. Untuk lebih jelasnya mengenai klasifikasi pada indikator kepadatan penduduk dapat dilihat pada gambar 5.11 berikut ini.

2. Analisis Kepadatan Bangunan

Analisis kepadatan bangunan akan dilakukan dengan menggunakan teknik analisis deskriptif kuantitatif dan spasial deskriptif. Analisis kepadatan bangunan dilakukan dengan menggunakan data jumlah bangunan yang dibagi dengan luas lahan terbangun pada masing-masing kelurahan di Kecamatan Tampan. Semakin tinggi kepadatan bangunan mengindikasikan tingkat sprawl yang semakin kecil (Hasse, John dan Richard dalam Apriani, 2015). Untuk lebih jelasnya dapat dilihat pada tabel berikut ini.

Tabel 11. Analisis Kepadatan Bangunan di Kecamatan Tampan Tahun 2016

\begin{tabular}{|c|c|c|c|c|}
\hline No & Kelurahan & 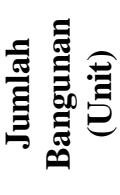 & 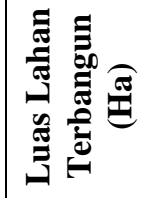 & 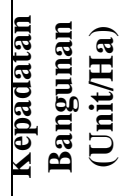 \\
\hline 1 & Simpangbaru & 13.586 & $1.797,90$ & 8 \\
\hline 2 & Sidomulyobarat & 12.651 & 728,34 & 17 \\
\hline 3 & Tuah Karya & 16.389 & 711,29 & 23 \\
\hline 4 & Delima & 9.404 & 543,15 & 17 \\
\hline \multicolumn{2}{|r|}{ Jumlah } & 52.030 & 80,68 & 16 \\
\hline
\end{tabular}

Sumber : BPS Pekanbaru, Arcgis 10.1 dan Hasil analisis, 2018

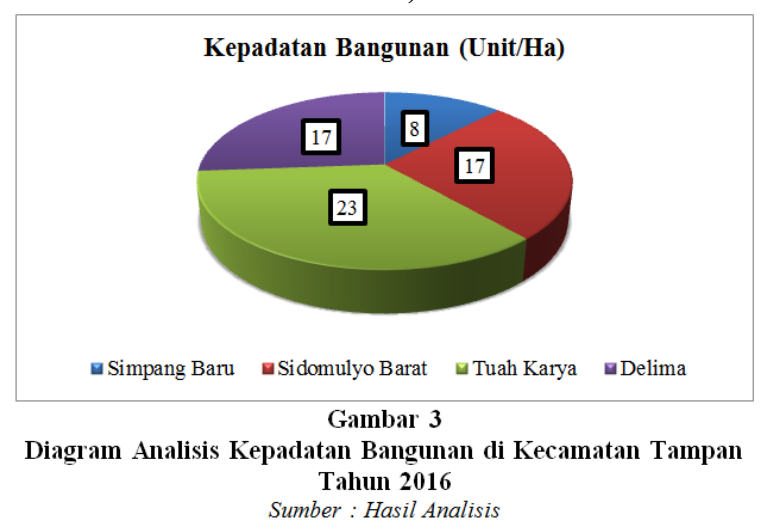


Berdasarkan perhitungan kepadatan bangunan pada tabel 5.9 dan diagram 5.9 diatas dapat dilihat bahwa kepadatan bangunan tertinggi adalah Kelurahan Tuah Karya dengan tingkat kepadatan bangunan 23 unit/ha, sedangkan kepadatan bangunan terendah terdapat di Kelurahan Simpang Baru dengan 8 unit/ha. Berdasarkan pada kepadatan bangunan tertinggi dan terendah kemudian dicari rentang nilai, sehingga didapat klasifikasikan kepadatan bangunan rendah, kepadatan bangunan sedang, dan kepadatan bangunan tinggi. Kelurahan dengan kepadatan bangunan rendah mengindikasikan tingkat urban sprawl yang semakin tinggi, sedangkan kelurahan dengan kepadatan bangunan tinggi mengindikasikan tingkat urban sprawl yang semakin rendah. Untuk menentukan range dan klasifikasi pada kepadatan bangunan dapat dilihat berikut ini.

$$
\begin{aligned}
& \text { Range Kelas }=\frac{\text { Nilai Tertinggi }- \text { Nilai Terendah }}{\text { Jumlah Kelas }} \\
& =\frac{23 \text { unit } / \text { ha }-8 \text { unit } / \mathrm{ha}}{3} \\
& =5 \mathrm{unit} / \mathrm{ha}
\end{aligned}
$$

Tabel 12. Klasifikasi Kepadatan Bangunan di Kecamatan Tampan

\begin{tabular}{|c|c|c|c|c|}
\hline No & $\begin{array}{c}\text { Range } \\
\text { Kelas }\end{array}$ & Kelurahan & Klasifikasi & Skor \\
\hline 1 & $8-13$ & Simpangbaru & Rendah & 3 \\
\hline 2 & $13-18$ & $\begin{array}{c}\text { Sidomulyobarat } \\
\text { dan Delima }\end{array}$ & Sedang & 2 \\
\hline 3 & $18-23$ & Tuah Karya & Tinggi & 1 \\
\hline
\end{tabular}

Sumber : Hasil analisis, 2018

Klasifikasi rendah dengan range 8-13 unit/ha terdapat di Kelurahan Simpang baru, untuk klasifikasi sedang dengan range 13-18 unit/ha yakni Kelurahan Sidomulyo barat dan Kelurahan Delima, sedangkan untuk klasifikasi tinggi dengan nilai range 18-23 unit/ha terdapat di Kelurahan Tuah Karya.

\section{Analisis Jarak Ke Pusat Kota}

Analisis jarak ke pusat kota dilakukan dengan mengukur jarak terjauh dari bangunan pada kelurahan urban sprawl ke wilayah pusat kota. Analisis dilakukan dengan menggunakan bantuan ArcGis 10.1 melalui network analysis. Semakin jauh jarak bangunan dalam kelurahan yang teridentifikasi sprawl dari pusat kota, maka tingkat sprawl semakin tinggi (Hasse, John dan Richard dalam Apriani, 2015).

Tabel 13. Analisis Jarak Ke Pusat Kota

\begin{tabular}{|c|l|c|}
\hline No & Kelurahan & $\begin{array}{c}\text { Jarak } \\
\text { Bangunan } \\
\text { Terjauh Ke- } \\
\text { Pusat Kota } \\
\text { (Km) }\end{array}$ \\
\hline 1 & Simpangbaru & 18,95 \\
\hline 2 & Sidomulyobarat & 15,69 \\
\hline 3 & Tuahkarya & 18,27 \\
\hline 4 & Delima & 11,92 \\
\hline
\end{tabular}

Sumber : Arcgis 10.1 dan Hasil analisis, 2018

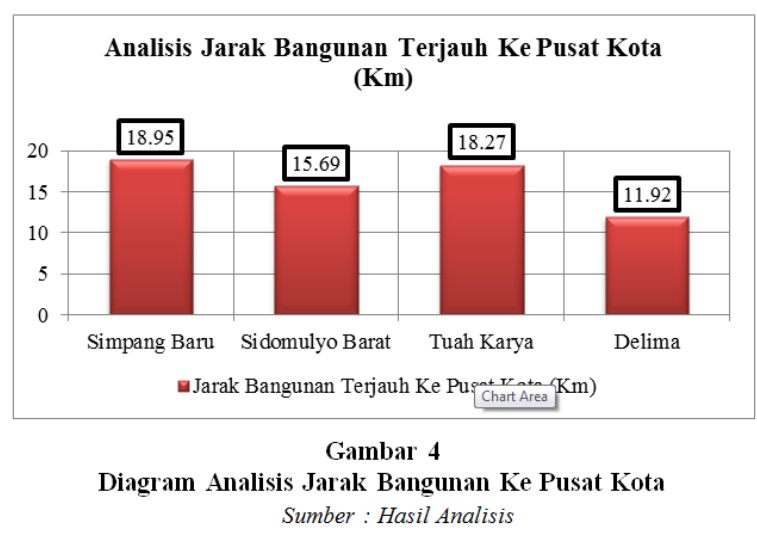

Hasil analisis jarak bangunan ke pusat kota pada gambar dan tabel 13 dan diagram 5.15 diatas maka dapat dilihat bahwa jarak bangunan terjauh pada masing-masing kelurahan urban sprawl terhadap pusat kota adalah Kelurahan Simpangbaru dengan jarak 18,95 Km sedangkan jarak kelurahan terdekat dengan pusat Kota adalah Kelurahan Delima berjarak 11,95 Km. 


$$
\begin{aligned}
& \text { Range Kelas }=\frac{\text { Jarak Terjauh }- \text { Jarak Terdekat }}{\text { Jumlah Kelas }} \\
& =\frac{18,95 \mathrm{Km}-11,92 \mathrm{Km}}{3} \\
& =2,34 \mathrm{Km}
\end{aligned}
$$

Tabel 14. Klasifikasi Jarak Ke Pusat Kota di Kecamatan Tampan

\begin{tabular}{|c|c|c|c|c|}
\hline No & $\begin{array}{c}\text { Range } \\
\text { Kelas }\end{array}$ & Kelurahan & Klasifikasi & Skor \\
\hline 1 & $\begin{array}{c}11,92 \\
- \\
14,27\end{array}$ & Delima & Rendah & 1 \\
\hline 2 & $\begin{array}{c}14,27 \\
- \\
16,61\end{array}$ & Sidomulyobarat & Sedang & 2 \\
\hline 3 & $\begin{array}{c}16,61 \\
-\end{array}$ & $\begin{array}{c}\text { Tuahkarya dan } \\
\text { Simpangbaru }\end{array}$ & Tinggi & 3 \\
\hline
\end{tabular}

Sumber : Hasil analisis, 2018

Berdasarkan pada hasil analisis jarak ke pusat kota klasifikasi sprawl rendah dengan nilai range $11,92 \mathrm{Km}$ $14,27 \mathrm{Km}$ terdapat pada Kelurahan Delima, untuk klasifikasi sprawl sedang dengan nilai range $14,27 \mathrm{Km}-16,61 \mathrm{Km}$ terdapat pada Kelurahan Sidomulyobarat dan untuk klasifikasi sprawl tinggi dengan nilai range $16,61 \mathrm{Km}-18,95 \mathrm{Km}$ terdapat pada Kelurahan Tuahkarya dan Simpangbaru.

\section{Analisis Pembangunan dalam Jangkauan Jaringan Jalan}

Analisis pembangunan dalam jangkauan jaringan jalan merupakan salah satu indikator dalam mengukur tingkat urban sprawl. Analisis pembangunan dalam jangkauan jaringan jalan dilakukan dengan fokus pada jalan utama, jalan kolektor maupun jalan lokal di wilayah yang teridentifikasi sprawl. Keberlanjutan jaringan jalan tersebut kemudian diukur dengan melakukan buffer pada jaringan jalan utama, yaitu $100 \mathrm{~m}$ seperti yang pernah dilakukan pada studi kasus di New Jersey. Kemudian untuk menentukan tingkat sprawl, maka dapat dihitung dengan menggunakan index highway strip.
Semakin besar rasio highways strip maka mengindikasikan tingkat sprawl semakin kecil (Hasse John and Richard, dalam Apriani 2015).

Data spasial yang diperlukan dalam melakukan analisis ini adalah jaringan jalan utama, kolektor maupun lokal pada wilayah urban sprawl dan bangunan baru tahun 2016 (perubahan bangunan yang terjadi antara tahun 20062016). Jaringan jalan diberi buffer (penyangga) selebar $100 \mathrm{~m}$ yang dilakukan dengan bantuan Arcgis 10.1. Analisis ini kemudian dimasukkan kedalam rumus index highway strip, yaitu jumlah bangunan baru yang masuk dalam jaringan jalan dibagi dengan jumlah total bangunan baru tahun 2016 .

Tabel 15. Analisis Pembangunan dalam Jangkauan Jaringan Jalan

\begin{tabular}{|c|l|c|c|c|}
\hline No & Kelurahan & $\begin{array}{c}\text { Jumlah } \\
\text { Bangunan } \\
\text { dalam } \\
\text { Buffer } \\
\text { (Unit) }\end{array}$ & $\begin{array}{c}\text { Jumlah } \\
\text { Bangunan } \\
\text { Baru } \\
\text { (Unit) }\end{array}$ & $\begin{array}{c}\text { Index } \\
\text { Highway } \\
\text { Strip }\end{array}$ \\
\hline 1 & Simpangbaru & 3.517 & 7.991 & 0,44 \\
\hline 2 & Sidomulyobarat & 2.065 & 5.383 & 0,38 \\
\hline 3 & Tuahkarya & 3.154 & 9.709 & 0,33 \\
\hline 4 & Delima & 1.264 & 2.465 & 0,51 \\
\hline
\end{tabular}

Sumber : BPS Pekanbaru, Arcgis, 10.1 dan Hasil analisis, 2018

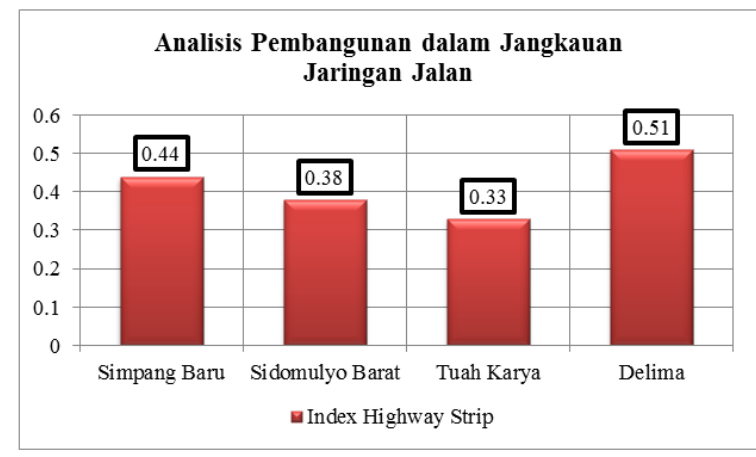

Gambar 5

Diagram Analisis Pembangunan dalam Jangkauan Jaringan Jalan Sumber : Hasil Analisis /

Berdasarkan analisis pembangunan dalam jangkauan jaringan jalan diatas dapat dilihat bahwa index highway strip yang terendah yaitu 0,33 terdapat di Kelurahan Tuah Karya dan 
yang tertinggi 0,51 yakni terdapat di Kelurahan Delima. Untuk langkah selanjutnya yakni untuk menentukan range kelas dan klasifikasi pada indikator pembangunan dalam jangkauan jaringan jalan yang dapat dilihat berikut ini.

$$
\begin{aligned}
& \text { Range Kelas }=\frac{\text { Nilai Tertinggi }- \text { Nilai Terendah }}{\text { Jumlah Kelas }} \\
& \begin{array}{c}
=\frac{0,51-0,33 \mathrm{Km}}{3} \\
=0,06 \mathrm{Km}
\end{array}
\end{aligned}
$$

Tabel 16. Klasifikasi Pembangunan dalam Jaringan Jalan di Kecamatan Tampan

\begin{tabular}{|c|c|c|c|c|}
\hline No & $\begin{array}{c}\text { Range } \\
\text { Kelas }\end{array}$ & Kelurahan & Klasifikasi & Skor \\
\hline 1 & $\begin{array}{c}0,33- \\
0,39\end{array}$ & $\begin{array}{c}\text { Sidomulyo } \\
\text { Barat dan } \\
\text { Tuah Karya }\end{array}$ & Rendah & 3 \\
\hline 2 & $\begin{array}{c}0,39- \\
0,45\end{array}$ & $\begin{array}{c}\text { Simpang } \\
\text { Baru }\end{array}$ & Sedang & 2 \\
\hline 3 & $\begin{array}{c}0,45- \\
0,51\end{array}$ & Delima & Tinggi & 1 \\
\hline
\end{tabular}

Sumber : Hasil analisis, 2018

Berdasarkan pada hasil analisis pembangunan dalam jangkauan jaringan jalan diatas dapat dilihat bahwa klasifikasi sprawl rendah dengan nilai range 0,33 0,39 terdapat pada Kelurahan Sidomulyo Barat dan Kelurahan Tuah Karya, untuk klasifikasi sprawl sedang dengan nilai range 0,39-0,45 terdapat pada Kelurahan Simpang Baru dan untuk klasifikasi sprawl tinggi dengan nilai range $0,45-0,51$ terdapat pada Kelurahan Delima.

\section{Analisis Pola Pembangunan Lompatan Katak}

Analisis pola pembangunan lompatan katak (leap frog) merupakan salah satu ciri utama dari pembangunan yang terfragmentasi yang mengindikasikan terjadinya sprawl. Sehingga leap frog merupakan salah satu indikator dalam pengukuran urban sprawl. Semakin tinggi nilai index leap frog menunjukkan bahwa tingkat urban sprawl yang semakin besar (Hasse John et.al dalam Apriani, 2015).
Analisis leap frog dilakukan dengan mengukur pola pembangunan yang terfragmentasi, yaitu mengukur jarak bangunan-bangunan baru ke pusat permukiman yang ada sebelumnya. Bangunan baru yang digunakan dalam pengukuruan ini adalah perubahan bangunan yang ada antara tahun 20062016 di kelurahan yang teridentifikasi sprawl, sedangkan bangunan lama merupakan bangunan yang ada pada tahun 2006 yang membentuk suatu permukiman. Pengukuran leap frog dilakukan dengan menggunakan analisis network untuk mengukur jarak antara pusat-pusat bangunan baru dengan pusat permukiman lama. Seluruh pusat-pusat bangunan baru diukur jaraknya terhadap pusat permukiman lama, kemudian jaraknya dimasukkan kedalam rumus index leap frog yakni membagi jumlah jarak bangunan baru terhadap bangunan lama dengan jumlah bangunan baru yang akan ditunjukan pada gambar 5.20 dan tabel 5.15 sebagai berikut.

Tabel 17. Analisis Pola Pembangunan Lompatan Katak

\begin{tabular}{|c|l|c|c|c|}
\hline No & Kelurahan & $\begin{array}{c}\text { Jumlah } \\
\text { Jarak } \\
\text { Bangunan } \\
\text { Baru } \\
\text { terhadap } \\
\text { Bangunan } \\
\text { Lama }\end{array}$ & $\begin{array}{c}\text { Jumlah } \\
\text { Bangunan } \\
\text { Baru } \\
\text { (Unit) }\end{array}$ & $\begin{array}{c}\text { Index } \\
\text { Leap } \\
\text { frog }\end{array}$ \\
\hline 1 & $\begin{array}{l}\text { Simpang } \\
\text { Baru }\end{array}$ & $28.806,62$ & 7.991 & 3,61 \\
\hline 2 & $\begin{array}{l}\text { Sidomulyo } \\
\text { Barat }\end{array}$ & $14.507,19$ & 5.383 & 2,70 \\
\hline 3 & $\begin{array}{l}\text { Tuah } \\
\text { Karya }\end{array}$ & $17.232,73$ & 9.709 & 1,78 \\
\hline 4 & Delima & $6.318,71$ & 2.465 & 2,56 \\
\hline
\end{tabular}

Sumber: BPS Pekanbaru, Arcgis, 10.1 dan Hasil analisis, 2018 


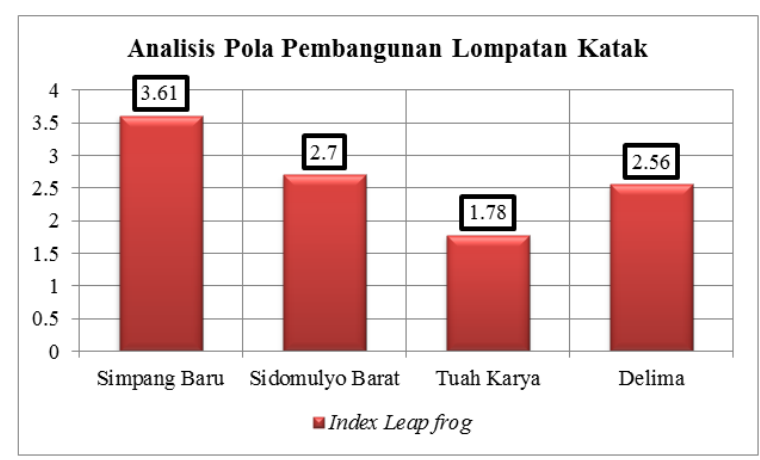

Gambar 6

Diagram Analisis Pola Pembangunan Lompatan Katak Sumber : Hasil Analisis

Berdasarkan analisis pola lompatan katak diatas dapat dilihat bahwa index leap frog yang terendah yaitu 1,78 pada Kelurahan Tuah Karya dan yang tertinggi 3,61 yaitu pada Kelurahan Simpang Baru. Untuk langkah selanjutnya yakni menentukan range kelas dan klasifikasi pada indikator pola lompatan katak yang dapat dilihat berikut ini.

$$
\begin{aligned}
& \text { Range Kelas }=\frac{\text { Nilai Tertinggi }- \text { Nilai Terendah }}{\text { Jumlah Kelas }} \\
& \begin{aligned}
&=\frac{3,61-1,78 \mathrm{Km}}{3} \\
&=0,61
\end{aligned}
\end{aligned}
$$

Tabel 18. Klasifikasi Pola Lompatan Katak di Kecamatan Tampan

\begin{tabular}{|c|c|c|c|c|}
\hline No & $\begin{array}{c}\text { Range } \\
\text { Kelas }\end{array}$ & Kelurahan & Klasifikasi & Skor \\
\hline 1 & $\begin{array}{c}1,78- \\
2,39\end{array}$ & Tuahkarya & Rendah & 1 \\
\hline 2 & $\begin{array}{c}2,39- \\
3,00\end{array}$ & $\begin{array}{c}\text { Sidomulyobarat } \\
\text { dan Delima }\end{array}$ & Sedang & 2 \\
\hline 3 & $\begin{array}{c}3,00- \\
3,61\end{array}$ & Simpangbaru & Tinggi & 3 \\
\hline
\end{tabular}

Sumber : Hasil analisis, 2018

Berdasarkan pada hasil analisis pola lompatan katak diatas dapat dilihat bahwa klasifikasi sprawl rendah dengan nilai range 1,78 - 2,39 terdapat pada Kelurahan Tuah Karya, untuk klasifikasi sprawl sedang dengan nilai range 2,393,00 terdapat pada Kelurahan Sidomulyo Barat dan Kelurahan Delima dan untuk klasifikasi sprawl tinggi dengan nilai range 3,00 - 3,61 terdapat pada Kelurahan Simpang Baru. Untuk melihat lebih jelas mengenai klasifikasi pada pola lompatan katak diatas dapat dilihat pada gambar 5.22 berikut ini.

Pengukuran tingkat urban sprawl di Kecamatan Tampan dilakukan dengan metode scoring dari hasil perhitungan tingkat sprawl pada kelima karakteristik urban sprawl yang telah dilakukan diatas. Pengukuran tingkat urban sprawl ini bertujuan untuk mengklasifikasikan tingkat urban sprawl dari kelurahan-kelurahan yang ada di Kecamatan Tampan yang akan dibagi kedalam tiga tipologi (kelompok), sehingga dapat diketahui kelurahankelurahan yang berada pada tipologi sprawl tinggi, tipologi sprawl sedang, dan tipologi sprawl rendah. Hasil dari pengelompokkan tingkat urban sprawl itu sendiri bertujuan untuk memberikan gambaran dalam bentuk rekomendasi kepada pemerintah kota terkait dengan kontrol perencanaan terhadap perkembangan kota.

Dalam mengukur tingkat urban sprawl, maka perlu dilakukan skoring terhadap variabel-variabel urban sprawl yang telah diklasifikasikan kedalam 3 tingkatan, yaitu rendah, sedang, dan tinggi. Masing-masing variabel yang telah di klasifikasikan memiliki indikasi yang berbeda terhadap tingkat urban sprawl. Variabel kepadatan penduduk, variabel kepadatan bangunan, dan variabel pembangunan dalam jangkauan jaringan jalan dalam klasifikasi rendah mengindikasikan sprawl yang tinggi, begitu juga sebaliknya. Sedangkan untuk variabel jarak ke pusat kota dan variabel pola pembangunan lompatan katak dengan klasifikasi tinggi mengindikasikan sprawl yang semakin tinggi. Sehingga untuk mempermudah perhitungan dilakukan skoring yang sama pada setiap variabel, dimana nilai 3 mengindikasikan sprawl tinggi, nilai 2 mengindikasikan sprawl sedang, dan nilai 1 mengindikasikan sprawl rendah. Berikut adalah skoring 
pada masing-masing variabel yang telah di klasifikasikan.

Tabel 20. Analisa Tingka Urban Sprawl di Kecamatan Tampan

\begin{tabular}{|c|c|c|c|c|c|c|c|}
\hline \multirow[b]{2}{*}{ No } & \multirow[b]{2}{*}{ Kelurahan } & \multicolumn{5}{|c|}{ Skor } & \multirow[b]{2}{*}{$\begin{array}{l}\text { Total } \\
\text { Skor }\end{array}$} \\
\hline & & $\begin{array}{c}\text { Kepadatan } \\
\text { Penduduk }\end{array}$ & $\begin{array}{c}\text { Kepadatan } \\
\text { Bangunan }\end{array}$ & $\begin{array}{l}\text { Jarak } \\
\text { Ke } \\
\text { Pusat } \\
\text { Kota }\end{array}$ & $\begin{array}{c}\text { Pembangunan } \\
\text { dalam } \\
\text { Jangkauan } \\
\text { Jaringan Jalan }\end{array}$ & $\begin{array}{c}\text { Pola } \\
\text { Pembangunan } \\
\text { Lompatan } \\
\text { Katak }\end{array}$ & \\
\hline 1 & $\begin{array}{l}\text { Simpang } \\
\text { Baru }\end{array}$ & 3 & 3 & 3 & 2 & 3 & 14 \\
\hline 2 & $\begin{array}{l}\text { Sidomulyo } \\
\text { Barat }\end{array}$ & 2 & 2 & 2 & 3 & 2 & 11 \\
\hline 3 & Tuah Karya & 1 & 1 & 3 & 3 & 1 & 9 \\
\hline 4 & Delima & 2 & 2 & 1 & 1 & 2 & 8 \\
\hline
\end{tabular}

Sumber : Hasil analisis, 2018

Setelah mendapatkan total skor untuk masing-masing kelurahan yang teridentifikasi sprawl, selanjutkan dilakukan pengklasifikasian untuk membentuk 3 tipologi. Pengklasifikasian dapat dilakukan dengan mencari range kelas.

$$
\begin{aligned}
& \text { Range Kelas }=\frac{\text { Nilai Tertinggi }- \text { Nilai Terendah }}{\text { Jumlah Kelas }} \\
& =\frac{14-8}{3} \\
& =2
\end{aligned}
$$

Tabel 21. Tipologi Tingkat Urban Sprawl di Kecamatan Tampan

\begin{tabular}{|c|c|c|c|c|}
\hline No & $\begin{array}{c}\text { Range } \\
\text { Kelas }\end{array}$ & Kelurahan & Tipologi & $\begin{array}{c}\text { Tingkat } \\
\text { Urban } \\
\text { Sprawl }\end{array}$ \\
\hline 1 & $8-10$ & $\begin{array}{c}\text { Delima dan } \\
\text { Tuah } \\
\text { Karya }\end{array}$ & $\mathbf{1}$ & Rendah \\
\hline 2 & $10-12$ & $\begin{array}{c}\text { Sidomulyo } \\
\text { Barat }\end{array}$ & $\mathbf{2}$ & Sedang \\
\hline 3 & $12-14$ & $\begin{array}{c}\text { Simpang } \\
\text { Baru }\end{array}$ & $\mathbf{3}$ & Tinggi \\
\hline
\end{tabular}

Sumber : Hasil analisis, 2018

Tingkat urban sprawl tipologi 1 dengan tingkat urban sprawl rendah terdapat pada Kelurahan Delima dan Kelurahan Tuahkarya. Kelurahan Delima merupakan wilayah terkecil di Kecamatan Tampan dengan luas wilayah $10,44 \mathrm{~km}^{2}$. Jika dilihat dari letak geografis, terletak paling mendekati pusat kota dibandingkan dengan kelurahan lainnya, sehingga untuk mendapatkan pelayanan di pusat kota tidak dibutuhkan biaya transportasi yang terlalu mahal. Sementara kelurahan Tuahkarya memilik luas $12,09 \mathrm{~km}^{2}$, terletak berbatasan dengan Kabupaten Kampar yang jaraknya cukup jauh dari pusat kota. Walaupun berada dalam tipologi yang sama namun Kelurahan Tuahkarya memiliki nilai skor 9, lebih tinggi bila dibandingkan dengan Kelurahan Delima. Pertumbuhan bangunan yang ada pada kedua kelurahan ini masih berada pada satu lingkungan yang sama dengan pola bangunan lama, sehingga kondisi urban sprawl tidak menjadi hal dominan. Penggunaan lahan didominasi oleh kawasan pemukiman, komersial perdagangan dan jasa, pendidikan, kesehatan, peribadatan.

Tipologi 2 dengan tingkat urban sprawl sedang terdapat pada Kelurahan Sidomulyo Barat. Kelurahan ini memiliki luas wilayah $13,69 \mathrm{~km}^{2}$ yang berbatasan langsung dengan Kecamatan Marpoyan Damai dan Kabupaten Kampar. Penggunaan lahan yang dominan yakni diperuntukkan sebagai kawasan perdagangan dan jasa, pendidikan, perkantoran, kesehatan, pergudangan serta kawasan permukiman. Dibeberapa bagian wilayah dikelurahan ini ditemukan polapola sprawl namun masih berada dalam jangkauan terhadap pola bangunan yang telah ada sebelumnya.

Tipologi 3 dengan tingkat urban sprawl tinggi terdapat pada Kelurahan Simpang Baru. Kelurahan ini memiliki luas wilayah terbesar di Kecamatan Tampan dengan 23,59 $\mathrm{km}^{2}$. Kelurahan ini menjadi kelurahan dengan tingkat urban sprawl tertinggi di Kecamatan Tampan karena masih banyaknya lahan kosong yang belum dimanfaatkan sehingga memicu pertumbuhan bangunan seiring bertambah jumlah penduduk pula. Kelurahan ini berbatasan dengan Kabupaten Kampar yang masih adanya mencirikan kehidupan pedesaan pada wilayah yang berbatasan langsung seperti ditemukan adanya penggunaan lahan untuk perkebunan, pertanian maupun perikanan. Namun pertumbuhan bangunan yang terus meningkat dikelurahan tersebut juga 
dipengaruhi karena adanya pusat pendidikan Universitas Islam Negeri (UIN) Suska yang memicu berkembangnya penggunaan lahan untuk bangunan seperti kos-kosan, perdagangan dan jasa lainnya, dan lain-lain.

\section{KESIMPULAN}

1. Berdasarkan peta persebaran lahan terbangun di Kecamatan Tampan dapat disimpulkan bahwa ada dua jenis tipe perembetan yang ditemukan yakni perembetan memanjang (ribbon development) dan perembetan meloncat (leap frog development). Perembetan memanjang (ribbon development) merupakan tipe perembetan yang dominan dikecamatan ini yang mana penggunaan lahan terbangun umumnya mengikuti jalur transportasi yang ada sebelumnya yang dapat dilihat di sepanjang jalan utama maupun kolektor seperti Jl. HR. Soebrantas, Jl. Soekarno Hatta, Jl. Tuanku Tambusai, Jl. Kubang Raya, J1. SM. Amin, J1. Delima, Jl. Kayu Jati, Jl. Taman Karya, Jl. Suka Karya, Jl. Cipta Karya, J1. Purwodadi dan jalan-jalan lainnya. Perembetan meloncat (Leap frog Development) tidak menjadi tipe yang dominan namun dapat ditemukan pada sisi-sisi dimasing-masing kelurahan di Kecamatan Tampan.

2. Setelah melakukan proses analisis pada lima indikator tingkat urban sprawl yakni kepadatan penduduk, kepadatan bangunan, jarak dari pusat kota, pembangunan dalam jangkauan jaringan jalan dan pola lompatan katak maka diperolehlah hasil tingkat urban sprawl di Kecamatan Tampan yang terbagi kedalam 3 kelas yakni tipologi 1 yang menunjukkan tingkat urban sprawl rendah yakni terdapat pada Kelurahan Delima dan Kelurahan Tuah Karya, tipologi 2 yang menunjukkan tingkat urban sprawl sedang yakni terdapat pada Kelurahan
Sidomulyo Barat dan tipologi 3 yang menunjukkan tingkat urban sprawl tinggi terdapat pada Kelurahan Simpang Baru.

\section{DAFTAR PUSTAKA}

Robinson, Tarigan. 2005. Perencanaan Pembangunan Wilayah, Medan: PT Bumi Aksara.

Mulyono, Sadyohutomo. 2008. Manajemen Kota dan Wilayah, Bandung: PT Bumi Aksara

Rustiadi, Saefulhakim, dan Panuju. 2009. Perencanaan dan Pengembangan Wilayah, Bogor : Crestpent Press dan Yayasan Obor Indonesia.

Sukirno, Sadono. 1992. "Pengantar Teori Makro Ekonomi" Jakarta: LPFE-UI, Bina Grafika.

Supawi, Pawenang. 2016. Modul Perkuliahan Lingkungan Ekonomi Bisnis, Surakarta: Program Pascasarjana, UNIBA.

Lutfi, Muta'ali. 2005. Teknik Analisis Regional Untuk Perencanaan Wilayah, Tata Ruang, dan Lingkungan, Bandung: Perpustakaan Geografi, UGM.

Paulus, Hariyono. 2010. Perencanaan Pembangunan Kota dan Perubahan Paradigma, Yogyakarta: Pustaka Pelajar.

Ali Kabul, Mahi. 2015. Teori dan Aplikasi Pengembangan Wilayah, Bandar Lampung: Prenadamedia Group

Sjafrizal, 2015. Ekonomi Wilayah dan Perkotaan, Padang: Raja Grafindo Prasada.

Nirwono, Joga. 2017. Mewariskan Kota Layak Huni, Jakarta: PT. Gramedia Pustaka Utama.

Desy, Ismyanti. 2015. "Studi Prioritas Pengembangan Infrastruktur di Wilayah Pinggiran Kota Pekanbaru. Skripsi Universitas Islam Riau, Pekanbaru.

College Journal Prima Mawitjere, Pendapatan Asli Daerah, 2013

Garika Ujianik Pristiwati, 2009. Arahan Pengembangan Wilayah Di Koridor 
Jalan Arteri Primer SidoarjoMojokerto Berdasarkan Tipologi Perkembangan Kawasan Perkotaan Dan Perubahan Struktur Ekonomi Analisis Sektor Unggulan dan Pengembangan Wilayah di Kota Bandar Lampung selama Tahun 2000-2012”, Surabaya: Skripsi, Program Studi PWK ITSN.

Saidah, 2013. Sistem Pembagian Kerja Berdasarkan Jenis Kelamin (Analisis Gender Terhadap Tenaga Kerja Perkebunan Kelapa Sawit Pt Muaratoyu Subur Lestari Di Kabupaten Paser), Universitas Mulawarman: Jurnal, FISIP.

Ruchyat Deni Djakapermana, Santun R.P. Sitorus, Marimin dan Ernan Rustiadi. 2005. Perhitungan Nilai Ekonomi Total Dalam Rangka Pemanfaatan Ruang Wilayah Pulau Kalimantan, Bogor: Jurnal, IPB

Iswahyudin A. Rahman. 2010. Analisis penentuan sektor unggulan perekonomian wilayah Kota Bima, Makasar: Skripsi, Sains dan Teknologi Universitas Islam Negeri Alauddin Makassar.

Aris Munandar, 2010. Analisis Ekonomi Dan Potensi Pengembangan Wilayah Kecamatan Gemolong, Kabupaten Sragen, Surakarta : Tesis, Universitas Sebelas Maret.

Badan Pusat Statistik, 2017. "Kabupaten Pelalawan Dalam Angka 2016", Kabupaten Pelalawan: BPS Kabupaten Pelalawan.

Dinas Penanaman Modal, 2017. "Daya Beli", Kabupaten Pelalawan: Dinas Penanaman Modal Kabupaten Pelalawan.
Dinas Badan Perencanaan Pembangunan Daerah, 2017. "Pendapatan Asli Daerah Per Kapita", Kabupaten Pelalawan: Dinas BAPPEDA Kabupaten Pelalawan.

Dinas Badan Perencanaan Pembangunan Daerah, 2017. "Tingkat Urbanisasi", Kabupaten Pelalawan: Dinas BAPPEDA Kabupaten Pelalawan.

Badan Pusat Statistik, 2017. "Pekerja Disektor Non Pertanian", BPS Kabupaten Pelalawan.

Badan Pusat Statistik, 2017. "Penduduk yang Bekerja Fulltimel Purna Waktu”, BPS Kabupaten Pelalawan.

Dinas Badan Perencanaan Pembangunan Daerah, 2017. "Pekerja dengan Tingkat Rupiah Diatas Upah Minimum Kabupaten", Kabupaten Pelalawan: Dinas BAPPEDA Kabupaten Pelalawan.

Dinas Penananaman Modal, 2017. "Kontribusi Investasi Terhadap $P A D$ ”, Kabupaten Pelalawan: Dinas Penanaman Modal Kabupaten Pelalawan.

Dinas Badan Pengelolaan Aset Daerah, 2017. "Kontribusi Sektor Tersier Terhadap PAD", Kabupaten Pelalawan: Dinas BPAD Kabupaten Pelalawan.

Undang-Undang Nomor 53 Tahun 1999 Tentang Pembentukan 8 (delapan) Kabupaten/Kota di Provinsi Riau.

Undang-Undang No. 26 Tahun 2007 Tentang Penataan Ruang.

Undang-Undang Nomor 33 Tahun 2004 Tentang Perimbangan Keuangan Antara Pusat dan Daerah Pasal 1 angka 18.

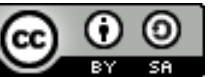

This is an open access article which means that all content is freely available without charge to the user or his/her institution. Jurnal Saintis allows the author(s) to hold the copyright without restriction. The copyright in the text of individual articles (including research articles, opinion articles, and abstracts) is the property of their respective authors distributed under the terms of the Creative Commons Attribution-ShareAlike 4.0 International License(https://creativecommons.org/licenses/by-sa/4.0/) which permits unrestricted use, distribution, and reproduction in any medium. Users are allowed to read, download, copy, distribute, search, or link to full-text articles in this journal without asking by giving appropriate credit, provide a link to the license, and indicate if changes
} were made. 